\title{
FILM ZOOTOPIA: ALTERNATIF MEDIA DALAM PENINGKATAN KEMAMPUAN MENULIS NARASI SISWA KELAS 8 SMP NEGERI 22 SURABAYA
}

\author{
Eni Soelistiowati, Sujinah, Ali Nuke Affandy \\ Universitas Muhammadiyah Surabaya \\ enisoelistiowati@gmail.com
}

\section{ABSTRAK}

ABSTRACT
Tujuan penelitian mendeskripsikan : 1. Kemampuan siswa menulis narasi sebelum menggunakan media film Zootopia. 2. Kemampuan siswa menulis narasi sesudah menggunakan media film Zootopia. 3. Pengaruh media film Zootopia terhadap kemampuan menulis narasi. 4. Respon guru dan siswa dalam pembelajaran menulis narasi menggunakan media film Zootopia. Jenis penelitian ini adalah penelitian kuantitatif. Simpulan : 1 . Kemampuan siswa dalam pembelajaran bahasa Indonesia menulis narasi sebelum menggunakan media film Zootopia, dapat dilihat dari nilai rata-rata pretest, yaitu sebesar 67,9 dengan kategori baik, dengan nilai tertinggi mencapai nilai 90, dan nilai terendah mencapai nilai 38,5. 2. Kemampuan siswa dalam pembelajaran bahasa Indoensia menulis narasi sesudah menggunakan media film Zootopia, dapat dilihat dari nilai rata-rata post test, yaitu sebesar 80 dengan kategori baik sekali, dengan nilai tertinggi mencapai nilai 91, dan nilai terendah mencapai nilai 69.3. Pengaruh media film Zootopia terhadap kemampuan menulis narasi siswa dapat dilihat dari adanya variasi dalam penyajian menulis narasi berupa penggunaan kalimat langsung, menandakan siswa sangat terbantu dalam menemukan gagasannya dalam menulis narasi dengan adanya upaya peneliti memberikan treatment panayangan media film Zootopia dalam pembelajaran bahasa Indonesia menulis narasi. 4. Respon guru dan siswa dalam pembelajaran menulis narasi menggunakan media film Zootopia, dapat di lihat dari respon guru dan siswa yang melebihi persentase di atas 50\%. Hal ini menunjukkan hasil yang positif dari sebaran angket yang diberikan kepada guru dan siswa kelas 8 I sebagai kelas eksperimen.

Kata Kunci: Media Film Zootopia, Menulis Narasi

The purpose of the study described: 1 . Ability of students to write narrative before using Zootopia film media. 2. Ability of students to write narrative after using Zootopia film media. 3 . The influence of Zootopia film media on the ability to write narrative. 4. Teacher and student responses in narrative writing lessons using Zootopia film media. This type of research was quantitative research. Conclusion: 1 . Ability of students in learning Indonesian of writing narrative before using Zootopia film media, can be seen from pretest average value, that was equal to 67,9 with good category, with highest score reached 90, and lowest score reached 38,5 . 2. The ability of students in learning Indonesian language of 
writing narrative after using Zootopia film media, can be seen from the average post test value, which was 80 with very good category, and the highest score reached 91, and the lowest score reached 69.3. The influence of Zootopia film media on the ability to write the narrative of students can be seen from the variation in the presentation of narrative writing namely using the direct sentences, indicating the students were very helpful in finding their ideas in writing the narrative with the efforts of researchers to provide treatment of viewing Zootopia film in Indonesian language of narrative writing. 4. Teacher and student responsed in narrative writing lessons using Zootopia film media exceed percentages above $50 \%$. This showed a positive result of the distribution of questionnaires given to teachers and students of grade $8 \mathrm{I}$ as an experimental class.

\section{Keywords: Zootopia Film Media, Narrative Writing}

PENDAHULUAN Menurut Tarigan (2008:3), keterampilan menulis merupakan satu keterampilan berbahasa yang dipergunakan untuk berkomunikasi secara tidak langsung, tidak secara bertatap muka dengan orang lain. Pengertian ini menunjukkan bahwa kegiatan menulis menjadi suatu kegiatan yang produktif dan ekspresif.

Di kehidupan sehari-hari seringkali siswa mendengar cerita, kemudian ditulis kembali pengalaman cerita tersebut dalam bentuk karangan yang disebut narasi. Karangan narasi adalah karangan yang menceritakan suatu kejadian secara runtut sesuai dengan urutan waktu (kronologis).

Karangan narasi tidak hanya bisa digunakan untuk menulis sebuah karya fiksi, tetapi juga fakta. Maka karangan atau tulisan narasi bisa digunakan untuk banyak tujuan seperti sejarah, novel, berita, biografi, dan lain-lain. Di dalamnya berinteraksi dalam berbagai konflik, disebut dengan plot atau alur secara sederhana. Karangan narasi adalah karangan atau tulisan yang dipaparkan berdasarkan plot atau alur.

Karangan narasi terbagi menjadi dua, yaitu: karangan narasi fiksi, dan karangan narasi non fiksi. Karangan narasi fiksi adalah karangan narasi yang mengisahkan cerita, peristiwa, atau kejadian nyata sesuai dengan imajinasi penulis. Termasuk dalam kategori ini adalah karangan narasi dalam bentuk tulisan novel, cerpen, legenda, dan lain-lain.

Sebaliknya karangan narasi non fiksi berupa cerita kejadian, atau peristiwa yang nyata berdasarkan investigasi (penyelidikan), observasi (pengamatan langsung), atau riset referensi. Kategori ini adalah karangan narasi dalam bentuk sejarah, biografi, autobiografi, kisah pengalaman, bentuk (baik straight news, maupun depht news), dan lain-lain.

Adapun maksud dan tujuan guru kepada siswa untuk menulis narasi adalah agar siswa lebih terampil memberikan informasi atau wawasan dan memberikan pengalaman estetis kepada pembaca. Peneliti mencermati bahwa pada umumnya guru bahasa Indonesia di SMP Negeri 22 Surabaya menggunakan metode mengajar secara 
konvensional, yaitu guru lebih banyak mengerjakan teori-teori dalam mencatat. Dalam proses seperti itu hanya akan melahirkan manusia terdidik dilingkungan SMP Negeri 22 Surabaya dengan intelektual statis dan kurang kreatif. Oleh karena itu, guru perlu menerapkan suatu metode yang dapat memberikan semangat baru bagi anak-anak didik agar dapat lebih kreatif lagi, yaitu dengan menggunakan media film.

Mengingat sedemikian sentral dan strategisnya keberadaan, kedudukan, dan fungsi peranan guru, munculnya berbagai aturan baik internasional maupun nasional. PBB melalu ILO dan UNESCO pada dasawarsa 1960-an dan pada tahun 1966 mengeluarkan ILO/UNESCO Recommendation Concerning That Status of Teachers yang mengatur seluk beluk guru sebagai profesi dan seorang profesional (Rahman, 2012:97).

Melihat peningkatan mutu pendidikan, maka penggunaan media pendidikan tidaklah diragukan lagi, karena merupakan suatu alternatif yang harus ditempuh bila menginginkan daya serap tinggi dan mutu pendidikan yang memadai. Dengan media film Zootopia diharapkan mampu merangsang pola pikir, wawasan dan penalaran siswa, memberikan aspirasi anak dalam berpendapat, berkreasi, berimajinasi, dan berapresiasi.

Dalam kurikulum 13 (K13), guru dituntut untuk lebih kreatif, inovatif, dalam pembelajaran agar pengetahuan yang diberikan lebih bermakna, dapat memberikan landasan pengetahuan yang kuat bagi siswa untuk membangun pondasi pengetahuannya khususnya dikaitkan dengan keterampilan menulis setelah melihat sebuah tayangan film Zootopia, siswa lebih mudah menulis narasi apa yang dilihat, dipahami, dan dicerna hikma dari cerita dari film tersebut.

Dari latar belakang masalah di atas, tujuan penelitian ini adalah sebagai berikut.

1. Mendeskripsikan kemampuan siswa kelas 8 I (kelas eksperimen) SMP Negeri 22 Surabaya tahun ajaran 2016/2017 menulis narasi menggunakan media film Zootopia.

2. Mendeskripsikan kemampuan siswa kelas 8 A (kelas kontrol) SMP Negeri 22 Surabaya tahun ajaran 2016/2017 menulis narasi menggunakan media film Zootopia

3. Mendeskripsikan pengaruh media film Zootopia terhadap kemampuan menulis narasi siswa kelas 8 I SMP Negeri 22 Surabaya tahun ajaran 2016/2017.

Berdasarkan tujuan tersebut, diperlukan beberapa teori tentang narasi. Menurut Keraf (2001:136), narasi dapat dibatasi sebagai suatu bentuk wacana yang sasaran utamanya adalah tindak tanduk yang dijalin dan dirangkaikan menjadi sebuah peristiwa yang terjadi dalam suatu waktu. Menurut Semi (1990:32), narasi merupakan bentuk percakapan atau tulisan yang bertujuan menyampaikan atau menceritakan rangkaian peristiwa atau pengalaman manusia berdasarkan perkembangan dari waktu ke waktu, dengan kata lain narasi adalah suatu bentuk wacana yang 
berusaha menggambarkan dengan sejelas-jelasnya kepada pembaca suatu peristiwa yang telah terjadi berdasarkan urutan waktu.

Sedangkan menurut Menurut Slamet (2007:103), narasi adalah ragam wacana yang menceritakan proses kejadian suatu peristiwa. Sasarannya adalah memberikan gambaran yang sejelas-jelasnya kepada pembaca mengenai fase, urutan, langkah, atau rangkaian terjadinya suatu hal. Adapun pendapat Sujanto (1988:111), narasi merupakan jenis paparan yang biasa digunakan oleh para penulis untuk menceritakan tentang rangkaian kejadian atau peristiwaperistiwa yang berkembang melalui waktu. Hal yang sama dikemukakan Wibowo (2001:59), narasi adalah bentuk tulisan yang menggarisbawahi aspek penceritaan atas suatu rangkaian peristiwa yang dikaitkan dengan kurun waktu tertentu, baik secara objektif maupun imajinatif.

Karangan narasi menurut Finoza (2002:191), adalah bentuk tulisan yang berusaha menciptakan, mengisahkan, merangkaikan tindak-tanduk perbuatan manusia dalam sebuah peristiwa secara kronologis atau tidak berlangsung dalam suatu kesatuan waktu.

Karangan narasi tidak hanya bisa digunakan untuk menulis sebuah karya fiksi, tetapi juga fakta. Maka karangan atau tulisan narasi bisa digunakan untuk banyak tujuan seperti sejarah, novel, berita, biografi, dan lain-lain. Di dalamnya berinteraksi berbagai konflik, disebut dengan plot atau alur secara sederhana. Karangan narasi adalah karangan atau tulisan yang dipaparkan berdasarkan plot atau alur.

Karangan narasi terbagi menjadi dua, yaitu a). Karangan narasi fiksi, dan 2). Non fiksi. Karangan narasi fiksi adalah karangan narasi yang mengisahkan cerita, peristiwa, atau kejadian nyata sesuai dengan imajinasi penulis, masuk dalam kategori ini adalah karangan narasi dalam bentuk tulisan novel, cerpen, legenda, dan lain-lain. Sebaliknya karangan narasi non fiksi berupa cerita kejadian, atau peristiwa yang nyata berdasarkan investasi (penyelidikan), observasi (pengamatan langsung), atau riset referensi. Kategori ini adalah karangan narasi dalam bentuk sejarah, biografi, autobiografi, berita (baik straight news maupun depht news), dan lain-lain.

Tulisan narasi merupakan sebuah tulisan yang sebagian berisi cerita. Meskipun didalamnya terdapat gambaran-gambaran untuk melengkapi cerita tersebut, namun secara utuh tulisan tersebut bersifat cerita. Karangan narasi adalah sebuah karangan yang menceritakan suatu rangkaian kejadian yang disusun secara urut sesuai dengan urutan waktu. Jadi narasi merupakan sebuah karangan yang dibuat berdasarkan urutan waktu kejadian (Semi, 1990:29).

Penelitian ini menggunakan jenis kuantitatif dengan desain penelitian yang dipakai adalah quasi eksperimental design tipe non equivalent control group design. Penelitian ini memiliki dua kelas yang masing-masing diberikan treatment yang berbeda. Kelas 8 I sebagai kelas eksperimen adalah kelas yang diberikan treatment 
berupa penggunaan media film Zootopia dalam pembelajaran bahasa Indonesia menulis narasi, sedangkan kelas 8 A sebagai kelas kontrol adalah kelas yang diberikan treatment tidak ada media film dalam pembelajaran bahasa Indonesia menulis narasi.

Populasi dalam penelitian ini adalah seluruh siswa kelas 8 SMP Negeri 22 Surabaya tahun ajaran 2016/2017 sebanyak 340 siswa. Adapun teknik pengambilan sampel dilakukan dengan cara purposive random sampling. Sampel yang akan diteliti yaitu kelas 8 I sebagai kelas eksperimen dengan jumlah siswa 38 anak, terdiri 20 anak laki, dan 18 anak perempuan dan kelas 8 A sebagai kelas kontrol, dengan jumlah siswa 39 anak, terdiri 19 anak laki, dan 20 anak perempuan.

Selanjutnya, tingkat keefektifan pembelajaran dilakukan dengan menggunakan nilai gain yang ternormalisasi. Nilai gain ternormalisasi dihitung dengan menggunakan persamaan sebagai berikut.

$$
\begin{aligned}
& g=\frac{\text { Skor post test }- \text { Skor pretest }}{\text { Skor maksimal }- \text { Skor minimal }} \\
& \text { Sumber : Karianingsih (2010:43) }
\end{aligned}
$$

Dengan kriteria keefektifan yang terinterpretasi dari nilai gain ternormalisasi keefektifan yang terinterpretasi dari nilai gain ternormalisasi (Meltzer dalam Karianingsih, 2010:43).

\section{Klasifikasi Menurut Meltzer}

\begin{tabular}{|c|c|}
\hline Nilai $<\mathbf{g}>$ & Kriteria \\
\hline $0,70 \leq \mathrm{n} \leq 1,00$ & Tinggi \\
\hline $0,30 \leq \mathrm{n} \leq 0,69$ & Sedang \\
\hline$<0,30$ & Rendah \\
\hline
\end{tabular}

Sumber : Meltzer (dalam Karianingsih, 2010:43)

Kemudian, untuk mencari hubungan antara variabel x (media film Zootopia) dan variabel y (kemampuan menulis narasi), digunakan rumus berikut.

$$
r_{x y}=\frac{N \sum X Y-\sum X \sum Y}{\sqrt{N \sum X^{2}-\left(\sum X\right)^{2}} \cdot \sqrt{N \sum Y-\left(\sum Y\right)^{2}}}
$$

Keterangan :

$r_{x y}:$ koefisien korelasi.

$X$ : skor tentang media film Zootopia.

$Y$ : skor tingkat kemampuan menulis narasi siswa.

$N$ : jumlah responden.

Selanjutnya, untuk Menentukan persamaan regresi linear menggunakan rumus berikut.

$$
\mathrm{Y}=\mathrm{a}+\mathrm{bX}
$$

Keterangan :

Y : variabel dependen (nilai yang diprediksikan).

$\mathrm{X}$ : variabel independen. 
a : konstanta (nilai $\mathrm{Y}$ apabila $\mathrm{X}=0$ ).

b : koefisien regresi.

\section{PEMBAHASAN Kemampuan Siswa Kelas 8 I (Kelas Eksperimen) SMP Negeri 22 Surabaya Menulis Narasi Menggunakan Media Film Zootopia}

Kemampuan siswa kelas 8 I sebagai kelas eksperimen SMP Negeri 22 Surabaya dalam pembelajaran bahasa Indonesia menulis narasi, dapat diketahui dari nilai rata-rata pada pretest kelas 8 I sebagai kelas eksperimen, yaitu sebesar 67,9 dengan kategori baik. Nilai tertinggi yang dicapai siswa, yaitu 85, dan nilai terendah yang dicapai siswa, yaitu 35. Adapun siswa yang memperoleh skor 80100 dengan kategori baik sekali, sebanyak 4 siswa dengan persentase sebesar 10,5\%, siswa yang memperoleh skor 66-79 dengan kategori baik, sebanyak 16 siswa dengan persentase sebesar $42,2 \%$, siswa yang memperoleh skor 56-65 dengan kategori cukup, sebanyak 12 siswa dengan persentase 31,5\%, siswa yang memperoleh skor 40-55 dengan kategori kurang, sebanyak 5 siswa dengan persentase $13,2 \%$, dan siswa yang memperoleh skor 0-39 dengan kategori gagal, sebanyak 1 siswa dengan persentase 2,6\%. Data tersebut dapat ditunjukkan pada histogram berikut, yang menunjukkan kemampuan siswa kelas 8 I sebagai kelas eksperimen SMP Negeri 22 Surabaya pada pretest.

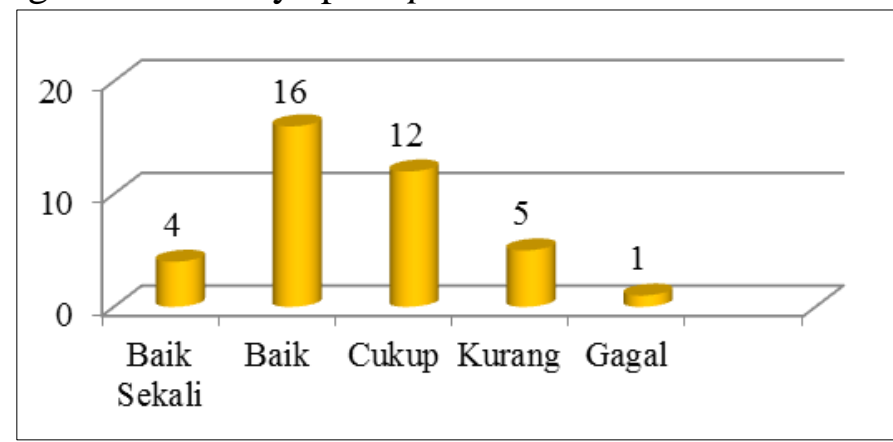

\section{Histogram Kemampuan Siwa Kelas 8 I (Kelas Eksperimen) SMP Negeri 22 Surabaya pada Pretest}

Berdasarkan hasil di atas, maka dapat dijelaskan bahwa kemampuan siswa kelas 8 I sebagai kelas eksperimen dalam menulis narasi pada pretest perlu mendapat perbaikan. Hal ini disebabkan nilai yang dicapai siswa masih rendah dengan rincian : sebanyak 1 siswa dikategorikan gagal, sebanyak 5 siswa dikategorikan kurang, dan sebanyak 12 siswa dikategorikan cukup. Rata-rata nilai yang dicapai siswa hanya sebesar 67,9 belum mencapai KKM SMP Negeri 22 Surabaya sebesar 70 dengan nilai tertinggi yang dicapai siswa kelas 8 I (kelas eksperimen) sebesar 85, dan nilai terendah yang dicapai siswa kelas 8 I (kelas eksperimen) sebesar 35.

Sedangkan kemampuan siswa kelas 8 I sebagai kelas eksperimen SMP Negeri 22 Surabaya dalam pembelajaran bahasa Indonesia menulis narasi, dapat diketahui dari nilai rata-rata post test kelas 8 I sebagai kelas eksperimen, yaitu sebesar 80 dengan 
kategori sangat baik. Nilai tertinggi yang dicapai siswa, yaitu 95, dan nilai terendah yang dicapai siswa, yaitu 70. Adapun siswa yang memperoleh skor 80-100 dengan kategori baik sekali, sebanyak 27 siswa dengan persentase sebesar $71,1 \%$, siswa yang memperoleh skor 66-79 dengan kategori baik, sebanyak 11 siswa dengan persentase sebesar 28,9\%, siswa yang memperoleh skor 56-65 dengan kategori cukup, sebanyak 0 siswa dengan persentase $0 \%$, siswa yang memperoleh skor 40-55 dengan kategori kurang, sebanyak 0 siswa dengan persentase $0 \%$, dan siswa yang memperoleh skor 0-39 dengan kategori gagal, sebanyak 0 siswa dengan persentase 0\%. Data tersebut dapat ditunjukkan pada histogram berikut, yang menunjukkan kemampuan siswa kelas 8 I sebagai kelas eksperimen SMP Negeri 22 Surabaya pada post test.

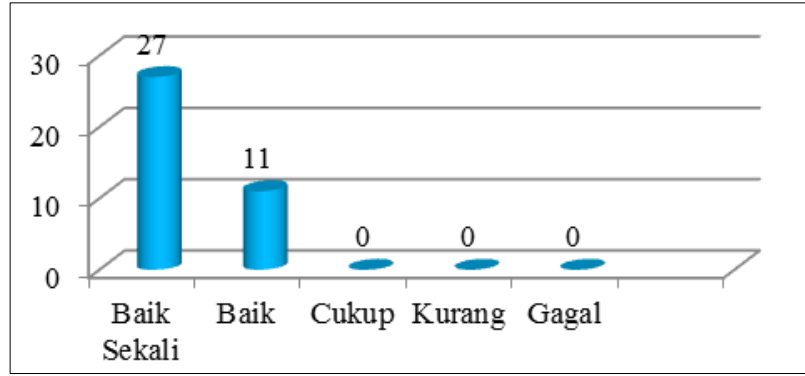

\section{Histogram Kemampuan Siwa Kelas 8 I (Kelas Eksperimen) SMP Negeri 22 Surabaya pada Post Test}

Berdasarkan hasil di atas, maka dapat dijelaskan bahwa kemampuan siswa kelas 8 I sebagai kelas eksperimen dalam menulis narasi pada post test telah mengalami perbaikan dan memenuhi KKM SMP Negeri 22 Surabaya sebesar 70. Nilai yang dicapai siswa secara keseluruhan telah dikategori baik sekali, tidak ada lagi siswa yang dikategorikan cukup, kurang maupun gagal. Rata-rata nilai yang dicapai siswa sudah ada perbaikan menjadi sebesar 80 dengan nilai tertinggi yang dicapai siswa kelas 8 I (kelas eksperimen) sebesar 95, dan nilai terendah yang dicapai siswa kelas 8 I (kelas eksperimen) sebesar 70.

Kemampuan Siswa Kelas 8 A (Kelas Kontrol) SMP Negeri 22 Surabaya Menulis Narasi Menggunakan Media Film Zootopia

Kemampuan siswa kelas 8 A sebagai kelas kontrol SMP Negeri 22 Surabaya dalam pembelajaran bahasa Indonesia menulis narasi, dapat diketahui dari nilai rata-rata pada pretest kelas $8 \mathrm{~A}$ sebagai kelas kontrol, yaitu sebesar 67,9 dengan kategori baik. Nilai tertinggi yang dicapai siswa, yaitu 90, dan nilai terendah yang dicapai siswa, yaitu 45. Adapun siswa yang memperoleh skor 80100 dengan kategori baik sekali, sebanyak 6 siswa dengan persentase sebesar 15,4\%, siswa yang memperoleh skor 66-79 dengan kategori baik, sebanyak 13 siswa dengan persentase sebesar 33,3\%, siswa yang memperoleh skor 56-65 dengan kategori cukup, sebanyak 12 siswa dengan persentase 31,5\%, siswa yang memperoleh skor 40-55 dengan kategori kurang, sebanyak 18 siswa dengan persentase $46,2 \%$, dan siswa yang memperoleh skor 0-39 
dengan kategori gagal, sebanyak 0 siswa dengan persentase $0 \%$. Data tersebut dapat ditunjukkan pada histogram berikut, yang menunjukkan kemampuan siswa kelas 8 A sebagai kelas kontrol SMP Negeri 22 Surabaya pada pretest.

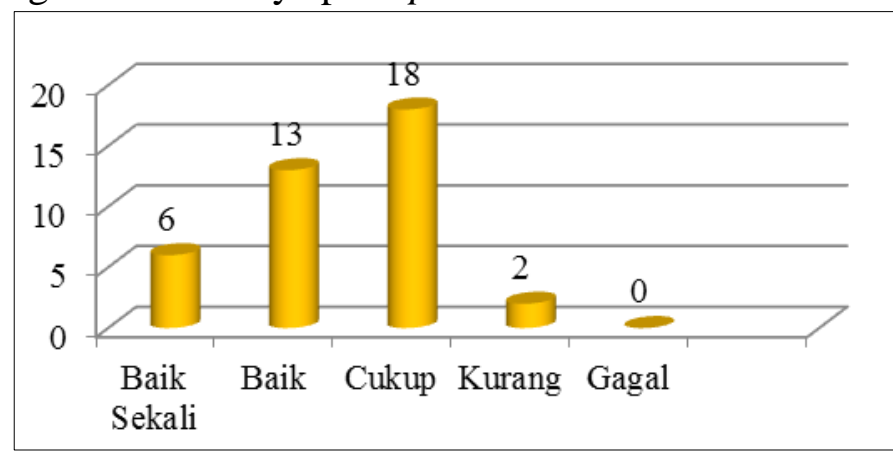

\section{Histogram Kemampuan Siwa Kelas 8 A (Kelas Kontrol) SMP Negeri 22 Surabaya pada Pretest}

Berdasarkan hasil di atas, maka dapat dijelaskan bahwa kemampuan siswa kelas 8 A sebagai kelas kontrol dalam menulis narasi pada pretest perlu mendapat perbaikan. Hal ini disebabkan nilai yang dicapai siswa masih rendah dengan rincian : sebanyak 2 siswa dikategorikan kurang, dan sebanyak 18 siswa dikategorikan cukup. Rata-rata nilai yang dicapai siswa hanya sebesar 67,9 belum mencapai KKM SMP Negeri 22 Surabaya sebesar 70 dengan nilai tertinggi yang dicapai siswa kelas 8 A (kelas kontrol) sebesar 90, dan nilai terendah yang dicapai siswa kelas 8 A (kelas kontrol) sebesar 45.

Sedangkan kemampuan siswa kelas 8 A sebagai kelas kontrol SMP Negeri 22 Surabaya dalam pembelajaran bahasa Indonesia menulis narasi, dapat diketahui dari nilai rata-rata post test kelas 8 A sebagai kelas kontrol, yaitu sebesar 79,1 dengan kategori sangat baik. Nilai tertinggi yang dicapai siswa, yaitu 95, dan nilai terendah yang dicapai siswa, yaitu 70. Adapun siswa yang memperoleh skor 80-100 dengan kategori baik sekali, sebanyak 21 siswa dengan persentase sebesar 53,9\%, siswa yang memperoleh skor 66-79 dengan kategori baik, sebanyak 18 siswa dengan persentase sebesar 46,1\%, siswa yang memperoleh skor 56-65 dengan kategori cukup, sebanyak 0 siswa dengan persentase $0 \%$, siswa yang memperoleh skor 40-55 dengan kategori kurang, sebanyak 0 siswa dengan persentase $0 \%$, dan siswa yang memperoleh skor 0-39 dengan kategori gagal, sebanyak 0 siswa dengan persentase $0 \%$. Data tersebut dapat ditunjukkan pada histogram berikut, yang menunjukkan kemampuan siswa kelas 8 A sebagai kelas kontrol SMP Negeri 22 Surabaya pada post test. 


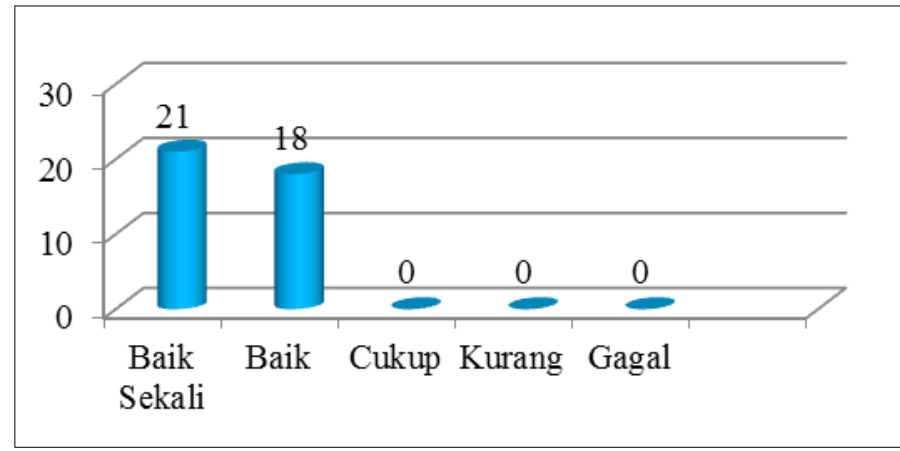

\section{Histogram Kemampuan Siwa Kelas 8 A (Kelas Kontrol) SMP Negeri 22 Surabaya pada Post Test}

Berdasarkan hasil di atas, maka dapat dijelaskan bahwa kemampuan siswa kelas 8 A sebagai kelas kontrol dalam menulis narasi pada post test telah mengalami perbaikan dan memenuhi KKM SMP Negeri 22 Surabaya sebesar 70. Nilai yang dicapai siswa secara keseluruhan telah dikategori baik sekali, tidak ada lagi siswa yang dikategorikan cukup, kurang maupun gagal. Rata-rata nilai yang dicapai siswa sudah ada perbaikan menjadi sebesar 79,1, dengan nilai tertinggi yang dicapai siswa kelas 8 A (kelas kontrol) sebesar 95, dan nilai terendah yang dicapai siswa kelas 8 I (kelas eksperimen) sebesar 70.

\section{Pengaruh Media Film Zootopia Terhadap Kemampuan Menulis Narasi Siswa Kelas 8 I SMP Negeri 22 Surabaya}

Pengaruh media film Zootopia terhadap kemampuan menulis narasi siswa kelas 8 I SMP Negeri 22 Surabaya. Saat pelaksanaan treatment, siswa terlihat sudah mulai terbiasa menulis narasi dengan menggunakan media film Zootopia sebagai treatment. Setelah menulis narasi, beberapa siswa yang memeriksa kembali pekerjaannya dan melakukan perbaikan. Hal tersebut dapat diartikan bahwa siswa jauh lebih tertarik dengan pembelajaran menulis narasi dengan menggunakan media film. Ada juga siswa yang masih belum memeriksa kembali hasil pekerjaannya, sibuk dengan kegiatan mereka masing-masing, seperti bermain, dan bercanda dengan rekan-rekannya. Hal ini sesuai pendapat Hamalik (2011:91), bahwa salah satu kelebihan yang dimiliki media film, yaitu menimbulkan dan mempertinggi minat siswa.

Berdasarkan hasil tabel berikut, dapat diketahui nilai rata-rata pada post test kelas 8 I sebagai kelas eksperimen, yaitu sebesar 80 dengan kategori baik sekali, ada peningkatan sebesar 12,1 dibandingkan nilai rata-rata pada pretest yang sebesar 67,9. Nilai tertinggi yang dicapai siswa pada post test, yaitu sebesar 95, ada peningkatan sebesar 10 dibandingkan nilai tertinggi yang dicapai siswa pada pretest, yaitu sebesar 85 , dan nilai terendah yang dicapai siswa pada post test, yaitu sebesar 70, ada peningkatan sebesar 35 dibandingkan nilai terendah yang dicapai siswa pada pretest, yaitu sebesar 35. Adapun siswa yang memperoleh skor 80-100 dengan kategori baik sekali, sebanyak 27 siswa dengan persentase sebesar 71,1\%, siswa yang memperoleh skor 66-79 dengan kategori baik, 
sebanyak 11 siswa dengan persentase sebesar 28,9\%, siswa yang memperoleh skor 56-65 dengan kategori cukup, sebanyak 0 siswa dengan persentase $0 \%$, siswa yang memperoleh skor 40-55 dengan kategori kurang, sebanyak 0 siswa dengan persentase $0 \%$, dan siswa yang memperoleh skor 0-39 dengan kategori gagal, sebanyak 0 siswa dengan persentase $0 \%$.

Tabel Perbandingan Hasil Nilai Pretest dan Post Test Kelas 8 I (Kelas Eksperimen)

\begin{tabular}{|c|c|c|c|c|c|c|}
\hline \multirow{2}{*}{ No } & \multirow{2}{*}{ Skor } & \multirow{2}{*}{ Kriteria } & \multicolumn{2}{c|}{$\begin{array}{c}\text { Frekuensi } \\
\text { Kelas 8 I }\end{array}$} & \multicolumn{2}{c|}{ Persentase (\%) } \\
\cline { 3 - 7 } & & Pretest & $\begin{array}{c}\text { Post } \\
\text { Test }\end{array}$ & Pretest & $\begin{array}{c}\text { Post } \\
\text { Test }\end{array}$ \\
\hline 1 & $80-100$ & Baik Sekali & 4 & 27 & 10,5 & 71,1 \\
\hline 2 & $66-79$ & Baik & 16 & 11 & 42,2 & 28,9 \\
\hline 3 & $56-65$ & Cukup & 12 & 0 & 31,5 & 0 \\
\hline 4 & $40-55$ & Kurang & 5 & 0 & 13,2 & 0 \\
\hline 5 & $0-39$ & Gagal & 1 & 0 & 2,6 & 0 \\
\hline \multicolumn{3}{|c|}{ Total } & 38 & 38 & 100 & 100 \\
\hline \multicolumn{3}{|c|}{ Rata-rata } & 67,9 & 80 & - & - \\
\hline \multicolumn{3}{|c|}{ Nilai Tertinggi Terendah } & 85 & 95 & - & - \\
\hline
\end{tabular}

Untuk lebih jelasnya dapat ditunjukkan pada Histogram berikut.

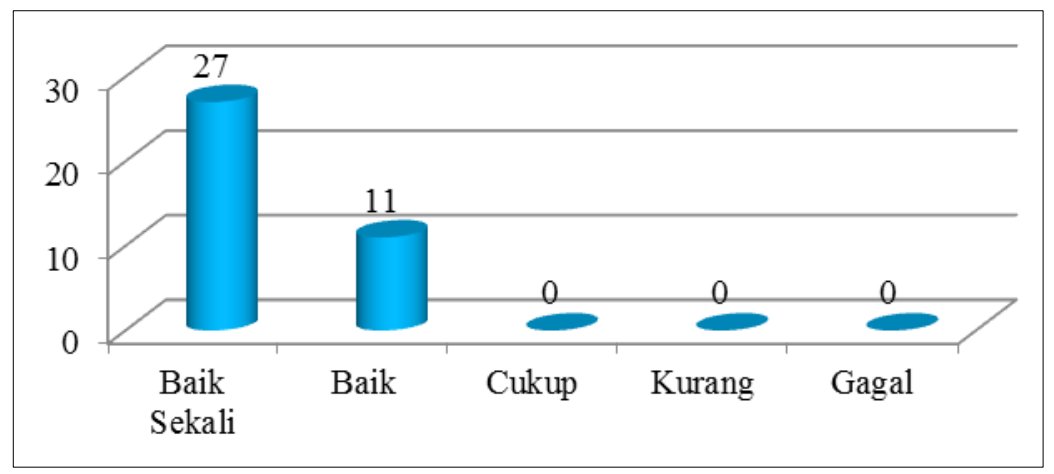

Histogram Hasil Nilai Post Test Kelas 8 I Kemampuan Menulis
Narasi Menggunakan Media Film Zootopia

Adapun pengaruh media film Zootopia terhadap kemampuan menulis narasi siswa kelas 8 I SMP Negeri 22 Surabaya. Jika ditinjau dari hasil tulisan narasi siswa kelas 8 I sebagai kelas eksperimen terlihat dari adanya variasai dalam penyajiannya yaitu berupa penggunaan kalimat langsung, yang menandakan bahwa siswa terbantu dalam menemukan gagasannya dalam menulis dengan adanya treatment berupa penayangan film Zootopia. Hal ini sesuai pendapat para ahli Basuki Wibawa dan Farida Mukti (1991:82), bahwa media film sebagai media pembelajaran dapat membantu siswa menemukan gagasan untuk mengawali kegiatan mengarang.

Berdasarkan hasil tersebut, dapat disimpulkan bahwa penggunaan media film Zootopia lebih efektif dalam pembelajaran 
bahasa Indonesia menulis narasi. Hal tersebut sesuai dengan pendapat ahli Arief S. Sadiman, dkk (2009:61), bahwa salah satu kelebihan yang dimiliki oleh film yaitu cocok untuk mengajarkan keterampilan, termasuk di dalamnya adalah keterampilan menulis narasi.

Saat awal pelaksanaan, siswa terlihat kurang percaya diri dengan hasil pekerjaan yang sudah dibuat, terlihat dari sebagian siswa tidak berani membacakan hasil pekerjaannya tesebut di depan kelas saat diminta oleh guru, ada lima siswa yang percaya diri dengan hasil pekerjaannya dan membacakan hasil pekerjaan yang sudah dibuat di depan kelas. Hal ini sesuai pendapat para ahli, Basuki Wibawa dan Farida Mukti (1991:82), bahwa film sebagai media pembelajaran dapat membantu mengatasi hambatan siswa yang kurang aktif.

\section{SIMPULAN}

Kemampuan siswa kelas 8 I sebagai kelas eksperimen SMP Negeri 22 Surabaya dalam pembelajaran bahasa Indonesia menulis narasi menggunakan media film Zootopia, dapat dilihat dari nilai rata-rata pada pretest, yaitu sebesar 67,9 dengan kategori baik, dengan nilai tertinggi mencapai nilai 85 dengan kategori baik, dan nilai terendah mencapai nilai 35 dengan kategori gagal, sedangkan nilai rata-rata pada post tes, yaitu sebesar 80, dengan kategori baik sekali, dengan nilai tertinggi mencapai nilai 95 dengan kategori baik sekali, dan nilai terendah mencapai nilai 70 dengan kategori cukup.

Kemampuan siswa kelas 8 A sebagai kelas kontrol SMP Negeri 22 Surabaya dalam pembelajaran bahasa Indonesia menulis narasi menggunakan media film Zootopia, dapat dilihat dari nilai rata-rata pretest, yaitu sebesar 67,9 dengan kategori baik, dengan nilai tertinggi mencapai nilai 90 dengan kategori baik sekali, dan nilai terendah mencapai nilai 45 dengan kategori kurang, sedangkan nilai rata-rata pada posttest, yaitu sebesar 79,1 dengan kategori baik sekali, dengan nilai tertinggi mencapai nilai 95 dengan kategori baik sekali, dan nilai terendah mencapai nilai 70 dengan dengan kategori baik.

Pengaruh media film Zootopia terhadap kemampuan menulis narasi siswa kelas 8 I sebagai kelas eksperimen SMP Negeri 22 Surabaya, dapat dilihat dari adanya variasi dalam penyajian menulis narasi berupa penggunaan kalimat langsung, menandakan siswa sangat terbantu dalam menemukan gagasannya dalam menulis narasi dengan adanya upaya peneliti memberikan treatment panayangan media film Zootopia dalam pembelajaran bahasa Indonesia menulis narasi. 
DAFTAR PUSTAKA

Abidin, Yunus. 2014. Desain Sistem Pembelajaran Dalam Konteks Kurikulum 2013. Bandung:PT. Refika Aditama.

Aji, Bayu Seno. 2011. Keefektifan Media Film Pendek Dalam Pembelajaran Menulis Cerpen pada Siswa Kelas X SMAN 1 Wadaslintang, Kecamatan Wadaslintang, Kabupaten Wonosobo.

Yogyakarta:Universitas Negeri Yogyakarta.

Ardianto, Elvinaro, dkk. 2009. Komunikasi Massa; Suatu Pengantar. Bandung:Simbioas Rekatama Media

Arikunto, Suharsimi. 2006. Prosedur Penelitian Suatu Pendekatan Praktik. Rineka Cipta, Jakarta.

Arsyad, Azhar. 2006. Media Pembelajaran. Jakarta:PT Raja Grafindo Persada.

Gagne, R.M. \& Briggs, L.J. 1975. Principles of Intructional Design. New York:Holt Rinehart and Winston.

Gerlach dan Ely. 1971. Teaching \& Media: A Systematic Approach, Second Edition, by V.S.

Hamalik, Oemar. 2011. Media Pendidikan. Bandung:Angkasa.

Jarwanto. 1990. Metodologi Induktif. Yogyakarta:BPFE.

Kemp, J.E dan Dayton, D.K. 2011. Planning and Producing Instructional Media. Cambridge: Harper \& Row Publishers, New York.
Rahman, Nazarudin. 2009. Regulasi Pendidikan : Menjadi Guru Profesional Pasca Sertifikasi. Yogyakarta:Pustaka Felich.

Rohcmawati, Annis. 2013. Penerapan Media Film Animasi Untuk Meningkatkan Kemampuan Menyimak Terhadap Mata Pelajaran Bahasa Indonesia Bagi Peserta Didik Kelas V MI Sudirman Kaliboto Mojogedang, Karanganyar, Tahun Pelajaran 2012/2013. Surakarta:Universitas Muhammadiyah.

Sadiman, Arief S, dkk. 2009. Media Pendidikan:

Pengertian,

Pengembangan, dan Pemanfaatannya. Jakarta:Rajawali Press

Soliah, Yuliatun Soliah. 2010. Peningkatan Kemampuan Bercerita Menggunakan Media Film Kartun Siswa Kelas VII F SMP Negeri 1 Mandiraja, Banjarnegara.

Semarang:Universitas Negeri.

Tarigan, Henry Guntur. 2011. Menulis Sebagai Suatu Keterampilan Berbahasa. Bandung:Angkasa.

Wibawa, Basuki dan Farida Mukti. 1991. Media Pengajaran. Jakarta:Departemen Pendidikan dan Kebudayaan Direktorat Jenderal Pendidikan Tinggi Proyek Pembinaan Tenaga Kependidikan 